\title{
Etude sur le virus de l'anémie contagieuse du cheval*
}

\author{
Observations expérimentales sur la \\ répartition du virus dans plusieurs \\ organes au cours de formes \\ évolutives non fébriles de \\ la maladie
}

\author{
par \\ N. Nakamura, S. Ishit et S. Watanabe. \\ Institut vétérinaire du Gouvernement japonais, Tokio \\ ( Cet éssai est celui qui a réproduit du raxport de \\ l'Offee International des Epizooties en 1938) \\ (reçu pour la publication Sept. 1, 1938)
}

\section{INTRODUCTION.}

La présence du virus de l'anémie contagieuse des chevaux a été confirmée par plusieurs auteurs dans le sang, dans la rate, dans le foie et dans les ganglions lymphatiques des chevaux atteints. On a reconnu aussi que le virus persiste longtemps dans la circulation sanguine d'animaux apparemment guéris de la maladie. D'après les rapports sur les expériences de l'Association japonaise pour la recherche de l'anémie contagieuse des chevaux, la présence du virus a été démontrée dans le sang d'animaux apparemment guéris, chez lesquels tous symptômes cliniques avaient disparu depuis quatre ans. Scott a aussi établi cette présence dans le sang des chevaux guéris depuis douze ans, et Schalk et Roderik chez des animaux dont la guérison remontait à quatorze ans. Néanmoins, d'après nos observations expérimentales sur la nature de ce virus, sa présence constante dans le sang des animaux apparemment guéris ne semble pas pouvoir être expliquée dans

* Japanese abstract pp. 214-216 
tous les cas, car il n'est pas possible de démontrer que ce virus est hémotrope; il est mésodermotrope et, dans les organes abdominaux, il semble de nature viscérotrope.

La virulence du sang prélevé sur les chevaux atteints différait avec les conditions dans lesquelles se trouvait le malade, suivant qu'il était en état fébrile ou non fébrile. La virulence la plus élevée du sang a été constatée au cours des accès fébriles.

En conséquence. il est raisonnable de supposer que la répartition du virus dans les divers organes de l'animal infecté doit être différente si l'évolution prolongée de la maladie se poursuit sans fièvre. Oppermann considérait que la localisation du virus dans quelques organes pouvait être mise en évidence pendant une semblable évolution de la maladie.

Nous nous sommes attachés à rechercher comment il était possible de démontrer la répartition du virus au cours d'une telle évolution. Les résultats obtenus semblent très intéressants pour l'appréciation de l'action pathogène de ce virus.

\section{EXPERIENCES}

Description des animaux.

Nous avons utilisé pour notre expérience 42 poneys provenant de Saishuto, île située au sud de la Corée et célèbre depuis de longues années pour son élevage de chevaux. Les poneys choisis, âgés de quatre ou cinq ans, avaient un mètre de hauteur. Ils n'avaient jamais été exposés dans l'île à l'infection par l'anémie contagieuse. Ils ont été trouvés sans exception sensibles à l'inoculation artificielle $d u$ virus. Chaque animal reçut en injection 0,01 à 0,002 centimètre cube de sang virulent de façon à présenter avec certitude les signes de l'infection après la période d'incubation d'une durée à peu près déterminée, le virus utilisé se multipliant facilement dans l'organisme par le passage consécutif à travers des poneys.

\section{Matériel.}

Les animaux atteints ont été abattus à divers moments au cours de l'évolution. Le matériel prélevé était mis en suspension 
dans la solution saline à la dilution de 1 pour 4 . Chaque prélèvement était maintenu à la glacière pendant cinq heures; un certain volume de la suspension, correspondant à un gramme de tissu naturel d'organe, était utilisè pour l'injection sous-cutanée. Quant au sang, un centimètre cube était dilué dans 4 centimètres cubes de solution saline et le tout inoculé.

\section{Résultats expérimentaux.}

A. Cas où la présence du virus a pu être démontrée dans chaque organe.-Le poney $\mathrm{N}^{\circ} 120$ a été traité par une injection sous-cutanée de 0,02 centimètre cube de sang virulent. Douze jours plus tard, il avait un accès de fièvre (le maximum de température atteignant $39^{\circ} \mathrm{C}, 5$ ). L'accès ne dura que deux jours. Au cours de l'observation clinique, qui porta sur 90 jours, un accès de fièvre modéré fut deux fois observé. Au soixantième jour après le dernier accès, le malade fut abattu et divers prélèvements furent inoculés á des poneys sains comme suit:

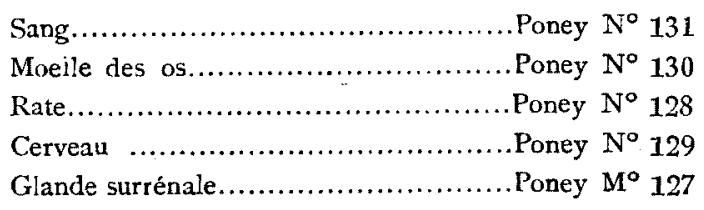

REMARQUES : Sang.-Erythrocytes : 7.720 .000 ; Leucocytes: 12.000 (Basophiles : 2,2 p. 100, Eosinophiles : 1,7 p. 100, Neutrophiles : 43,3 p. 100, Lymphocytes : 52,8 p. 100); Hémoglobine: 70 p. 100.

Ni elle des os.-Moelle rouge des os en grande quantité. L'érythropoièse et la leucopoièse ne sont pas faibles. L'hémosidérine est présente dans les capillaires aussi bien que dans les cellules réticuloendothéliales.

Rate.-On la trouve quelque peu tuméfiée avec un parenchyme ramolli et une distension prononcée des follicules. L'hyperémie et l'hémosidérine sont considérables; dans la zone du centre germinatif des follicules, une abondance des cellules propres peut être observée, mais celles-ci sont mélangées à des monocytes de petites dimensions (cellules lymphoïdes). Les noyaux de ces cellules 
ont une coloration foncée.

Cerveau.-Les petits vaisseaux sont largement dilatés par l'hyperémłe; une prolifération considérable de cellules névrogliques dans la corne d'Ammon est observée. On rencontre dans les vaisseaux du noyau caudé (nucleus caudatus) des figures d'éosinophilie.

Glande surrénale.-Dégénérescence très marquée des cellules situées entre la zone réticulée et la zone fasciculée, provoquant de la chromatolyse ou du gonflement du protoplasme. Les autres cellules corticales sont atteintes de pycnose et présentent des processus de dégénérescence. Dans la substance médullaire, augmentation de volume des cavités veineuses; une grande partie des cellules épithéliales cylindriques autour de la cavité présentent de la pycnose.

Les résultats expérimentaux, observés chez chaque animal inoculé, sont indiqués ci-dessous :

\begin{tabular}{|c|c|c|c|c|}
\hline $\begin{array}{l}\text { Désignation } \\
\text { des animaux }\end{array}$ & $\begin{array}{c}\text { Pêriode } \\
\text { d'incubation }\end{array}$ & $\begin{array}{l}\text { Degrê du } \\
\text { paroxysme }\end{array}$ & $\begin{array}{c}\text { Forme de la } \\
\text { maladie }\end{array}$ & Remarques \\
\hline- & 一 & - & - & - \\
\hline 131 & 18 jours & Fort & Subaiguë & - \\
\hline 130 & $21-$ & Fort & Subaiguë & - \\
\hline 128 & $38-$ & Fort & Chronique & - \\
\hline 129 & $42-$ & Moins fort & Chronique & - \\
\hline 127 & $34-$ & Fort & Aiguë & Mort \\
\hline
\end{tabular}

B. Cas où la présence du virus a pu être nettement démontrée dans le sang et dans les organes spéciaux hématopoiétiques, mais non dans le foie.-Le poney $\mathrm{N}^{\circ} 81$ a reçu un centimètre cube de sang virulent dans la chambre antérieure de l'oeil; douze jours après, il avait un accès de fièvre (le maximum de la température a été de $\left.41^{\circ} \mathrm{C}, 1\right)$. L'accès dura neuf jours. Au cours de l'observation clinique, d'une durée de deux mois, aucun autre accés de fièvre ne fut observé. Le malade fut abattu. On préleva sur ce malade divers matériaux qui ont été inoculés à des poneys comme suit:

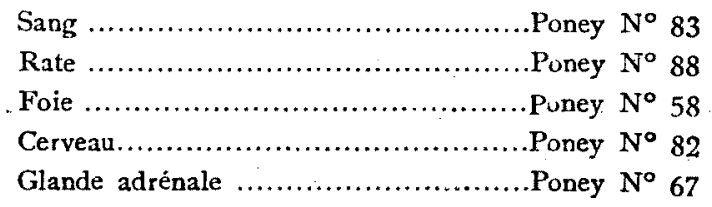


Remarques: Sang.-Erythrocytes : 8.550.000 ; Leucocytes : 9.300 (Eosinophiles : 3,8 p. 100 ; Neutrophiles : 50 p. 100 ; Lymphocytes: 43,3 p. 100 ; Histiocytes : 2,8 p. 100); Hémoglobine : 88 p. 100.

Rate.-Légérement plus volumineuse et dure. Pas de gonflement des follicules clos, absence d'amincissement des trabécules; dépôt moins important d'hémosidérine dans la pulpe et les sinus, et prolifération des fibres du réseau alvéolaire.

Foie.-Légère augmentation de volume avec aspect général réticulé. On note la présence d'un peu d'hémosidérine dans les cellules de l'endothélium vasculaire et une légère infiltration de cellules lymphoïdes dans la capsule de Glisson.

Cerveau.-Présence périvasculaire de taches hémorragiques dans la région du noyau caudé. Prolifération de cellules de la névroglie et dilatation des capillaires dans toutes les parties observées.

Glandes surrénales.-Hyperémie des capillaires surtout dans les zones réticulère et fasciculée. Léger processus de dégénérescence dans la région de la zone fasciculée et infiltration éosinophile et de cellules lymphoïdes dans l'intervalle de ces bandes cellulaires.

Les observations relevées sur chaque animal peuvent étre résumées comme suit:

\begin{tabular}{|c|c|c|c|}
\hline $\begin{array}{l}\text { Désignation } \\
\text { de: animaux }\end{array}$ & $\begin{array}{c}\text { Periode } \\
\text { d'incubat on }\end{array}$ & $\begin{array}{l}\text { Degré du } \\
\text { paroxysme }\end{array}$ & $\begin{array}{c}\text { Forme de la } \\
\text { maladie }\end{array}$ \\
\hline- & - & - & 一 \\
\hline 83 & 21 jours & Fort & Subaiguë \\
\hline 88 & $100-$ & Léger & Chronique \\
\hline 58 & $\begin{array}{l}\text { Aucun sympto } \\
\text { pendant } 158\end{array}$ & $\begin{array}{l}\text { e clinique } n \\
\text { urs aprês } l^{\prime} i\end{array}$ & $\begin{array}{l}\text { a être ob=ervé } \\
\text { ion. }\end{array}$ \\
\hline 82 & 40 jours & Léger & Chronique \\
\hline 67 & $22-$ & Lėger & Chronique \\
\hline
\end{tabular}

C. Cas où le virus est abondamment prézent dans le systeme nerveux central aussi bien que dans les organes endocriniens, mais où il est en trìs faible quantité dans les organes hématopoiétiques a l'exccption, toutefois, de la moelle des os.-Le poney $\mathrm{N}^{\circ} 96$ a reçu en injection sous-cutanée 0,05 centimétre cube de sang virulent. Des oscillations irrégulières de température furent enregistrées après l'injection. Le premier accès de fièvre $\left(39^{\circ} \mathrm{C}, 5\right)$ fut observé 55 
jours plus tard; le second accès (le maximum de température étant de $\left.39^{\circ} \mathrm{C}, 7\right)$ a duré cinq jours à partir du centième jour après l'inoculation du virus. Quinze jours plus tard, on enregistra un troisième accès et un autre après 70 jours. L'animal fut abattu et plusieurs prélèvements opérés sur ce sujet furent inoculés à des poneys sains comme suit:

\begin{tabular}{|c|c|}
\hline 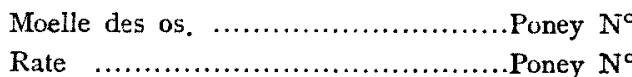 & \\
\hline Ganglion lymphatique .................Poney $\mathrm{N}^{\circ}$ & \\
\hline ..Poney $\mathrm{N}^{\circ}$ & \\
\hline ...Poney $\mathrm{N}^{\circ}$ & \\
\hline$\ldots \ldots \ldots \ldots$ Poney $\mathrm{N}^{\circ}$ & \\
\hline Portion lombaire de la moelle èpinière..Poney $\mathrm{N}^{\circ}$ & \\
\hline Glande surrénale $\ldots \ldots \ldots \ldots \ldots \ldots \ldots$.................. $\mathrm{N}^{\circ}$ & \\
\hline ...Poney $\mathrm{N}$ & \\
\hline
\end{tabular}

Remarques: Moelle des os.-Dépôt important d'hémosicérine; diminution de l'érythropoièse aussi bien que de la leucopoièse et diminution des mégacaryocytes.

Rate-Légère augmentation de volume, gonflement modéré des follicules lymphatiques et hyperémie dans la pulpe et les sinus, où les cellules ayant phagocyté l'hémosidérine sont extrêmement diminuées.

Ganglion lymphatique.-Gonflement oedémateux avec hyperémie. Diminution du nombre des cellules réticulo-endothéliales. On observe quelques cellules lymphoïdes dans les follicules. On n'a trouvé nulle part d'hémosidérine.

Foie.-Présente l'aspect réticulé avec une légère augmentation de volume. Dilatation des capillaires autour des cellules hépatiques, pas de sidérocyte, mais moins de cellules lymphoïdes dans les vaisseaux et légère distension des cellules endothéliales. sans hémosidérine.

Rein.-Légère augmentation de volume. Glomérulonéphrite provoquant le gonflement des endothéliums glomérulaires. Prolifération des cellules épithéliales dans les tubes contournés.

Cerveau.-Hyperémie des vaisseaux et prolifération des cellules de la névroglie dans la corne d'Ammon et le corps strié, qui s'- 
a'joute à celle des cellules de l'épendyme dans une partie du noyau caudé.

Portion lombaire de la moelle épinière.-Prolifération des cellules de l'épendyme autour du canal central et hyperémie générale des petits vaisseaux dans la substance grise.

Glande surrénale.-Hyperémie générale et surtout lésion très importante dans la zone réticulée de la portion corticale ainsi que dans la zone fasciculée, contiguë à cette portion. Lésion de dégénérescence des cellules dans la couche corticale. Les cellules ont des volumes très variables et qnelques-unes présentent de la pycnose. Infiltration modérée de cellules lymphoïdes dans une partie de la zone glomérulaire et de la zone fasciculée.

Glande thyroïde.-Légère atrophie avec dimension irrégulière des follicules et forme aplatie des cellules épithéliales. On note une mauvaise coloration du protoplasma et du noyau et de l'hyperémie du tissu interstitiel, environnée d'une légère infiltration de cellules mononucléaires.

Les résultats de l'inoculation des matériaux ci-dessus mentionnés sont indiqués ci-dessous :

\begin{tabular}{|c|c|c|c|c|}
\hline $\begin{array}{l}\text { Lésigna'ion } \\
\text { des animaux }\end{array}$ & $\begin{array}{c}\text { Période } \\
\text { d'incubation }\end{array}$ & $\begin{array}{l}\text { Degré } d u \\
\text { paroxysme }\end{array}$ & $\begin{array}{l}\text { Forme de la } \\
\text { maladie }\end{array}$ & Femarques \\
\hline- & - & - & - & - \\
\hline 124 & 15 jours & Trés fort & Aiguë & Mort \\
\hline 108 & $30-$ & Léger & Chronique & 一 \\
\hline 110 & \multicolumn{3}{|c|}{$\begin{array}{l}\text { Il n'a été relevé aucun symptôme clinique } \\
\text { un délai de } 180 \text { jours après l'injection. }\end{array}$} & pendant \\
\hline 109 & 24 jours & Modéré & Chronique & - \\
\hline 112 & $50-$ & Fort & Chronique & - \\
\hline 121 & $15-$ & Très fort & Aiguë & - Mort \\
\hline 126 & $2 L-$ & Léger & Chronique & - \\
\hline 111 & $17-$ & Très fort & Aiguë & Mort \\
\hline 114 & $17-$ & Fort & Chronique & - \\
\hline
\end{tabular}

D. Cas dans lesquels la présence du virus en abondance a pu être démontrêe dans le sang et dans les divers organes hematopoictiques, mais non dans d'autres organes où il n'existait pas.

Il a été inoculé au poney $\mathrm{N}^{\circ} 173$, par injection sous-cutanée, . 3 centimétres cubes de sang virulent. Treize jours après, l'animal 
avait un accès de fièvre (la température maximum a été de $39^{\circ} \mathrm{C}$, 7). Pendant sept jours, la fièvre s'est maintenue au même degré sans rémission. Toutefois, il n'a pas été observé d'accès de fièvre pendant deux mois et demi après. Le malade a été abattu et le matériel prélevé a été expérimentalement utilisé comme suit:

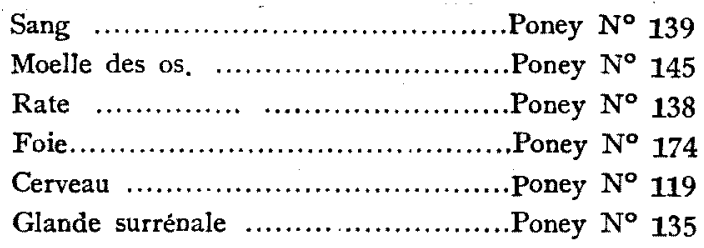

REMARQUES : Sang.-Erythrocytes : 5.380 .000 ; Leucocytes : 9.000 ; (Eosinophiles : 0,8 p. 100 ; Neutrophiles : 30 p.100 ; Lymphocytes : 69,2 p. 100); Hémoglobine : 62 p. 100.

Moelle des os.-Peu de moelle osseuse rouge. Présence autour des vaisseaux de follicules lymphoïdes métastatiques dans le tissu réticulé; diminution de l'érythropoièse et de la leucopoièse. Léger dépôt d'hémosidérine. Diminution des mégacaryocytes et infiltration importante d'éosinophiles.

Rate-Aucun changement dans le volume. Léger dépôt d'hémosidérine dans la pulpe et dans les sinus. Léger ramollissement de la pulpe avec forte coloration rouge, augmentation de volume des follicules lymphoïđes et prolifération des cellules réticulo-endothéliales dans le centre germinatif.

Foie.-Aspect légèrement réticulé avec un peu d'augmentation du volume; faible dilatation des capillaires, mais la présence de cellules lymphoïdes aussi bien que de larges monocytes a été rarement observée. Pas de dépot d'hémosidérine.

Cerveau.-Pas de lésion histologique observée.

Glande surrênale-Augmentation de volume des cellules dans la zone réticulée et la partie de la zone fasciculée qui est en rapport avec elle; quelques-unes des cellules atteignent six à sept fois et plus la dimension normale. Lésions de dégénérescence dans la plupart des cellules corticales, parmi lesquelles, on observe une prolifération du tissu conjonctif; l'hyperémie de la zone réticulère et lésions dégénératives de quelques cellules épithéliales cylindri- 
ques autour de l'espace veineux dans la substance médullaire.

Les résultats obtenus dans une série d'expériences d'inoculation sont les suivants :

\begin{tabular}{|c|c|c|c|}
\hline $\begin{array}{l}\text { Désignation } \\
\text { des animaux }\end{array}$ & $\begin{array}{c}\text { Période } \\
\text { d'incubation }\end{array}$ & $\begin{array}{l}\text { Degré du } \\
\text { pxroxysme }\end{array}$ & $\begin{array}{c}\text { Forme de la } \\
\text { maladie }\end{array}$ \\
\hline- & - & - & - \\
\hline 139 & 24 jours & Fort & Chronique \\
\hline 145 & $27-$ & Modéré & Chrunique \\
\hline 138 & $27-$ & Modéré & Chronique \\
\hline 174 & \multirow{3}{*}{\multicolumn{3}{|c|}{$\begin{array}{l}\text { Aucun symptôme clinique n'a été observé } \\
\text { dans ces cas, dans un dẻlai de } \\
180 \text { jours après l'injection du matériel. }\end{array}$}} \\
\hline 119 & & & \\
\hline 135 & & & \\
\hline
\end{tabular}

E. Cas où l'existence du virus a pu être demon'ré dans le système nerveux central aussi bien que dans les organes endocriniens, mais non dans les organes hémopoiétiques, à l'exception de la moelle des os. -Le poney $\mathrm{N}^{\circ} 176$ a reçu, par injection sous-cutanée, 3 centimètres cubes de sang virulent. Il a eu, 31 jours après, le premier accès de fièvre (le maximum de la température a été de $39^{\circ} \mathrm{C}, 8$ ). Il eut un second accès de fiévre après 17 jours (maximum de la température $\left.: 39^{\circ} \mathrm{C}, 5\right)$. Mais on n'observa aucun accès dans les sept mois et demi qui suivirent. Le malade fut alors abattu et plusieurs prélèvements furent expérimentalement utilisés comme suit :

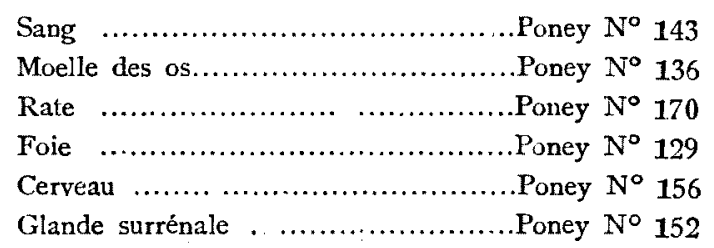

Remarques : Sang.-Erythrocytes : 5.160 .000 ; Leucocytes : 9.000 (Eosinophiles : 2,7 p. 100 ; Neutrophiles : 52,7 p. 100 ; Lymphocytes : 40,6 p. 100; Histiocytes : 4.1 p. 100; Hémoglobine : 51 p. 100.

Moelle des os.-Apparition de follicules lymphoïdes métastatiques dans le tissu réticulé. Diminution importante de l'érythropoièse et de la leucopoièse, diminution des mégacaryocytes, augm- 
entation des éosinophiles et prolifération des "silver fiber".

Rate-Ramollissement et hyperémie de la pulpe. Légère atrophie des follicules. Diminution des cellules propres et prolifération des "silver fiber" dans la pulpe, follicules et sinus.

Foie.-Légère hypertrophie. Dilatation des capillaires. Faible augmentation de volume des cellules étoilées sans hémosidérine et prolifération des "silver fiber".

Cerveau.-Hyperémie des petits vaisseaux. Cellules histiocytes et éosinophiles dans les vaisseaux dont le volume est augmenté; prolifération considérable des cellules de la névroglie; neuronophagie dans les diverses parties et légère infiltration périvasculaire de cellules mononucléaires.

Glande surrénale.-Dilatation des capillaires dans les zones réticulée et glomérulaire, où la plupart des cellules sont en voie de dégénérescence et lésions de dégénérescence des cellules cylindriques autour de l'espace veineux dans la substance médullaire.

Les résultats de chaque expérience d'inoculation sont indiqués ci-dessous :

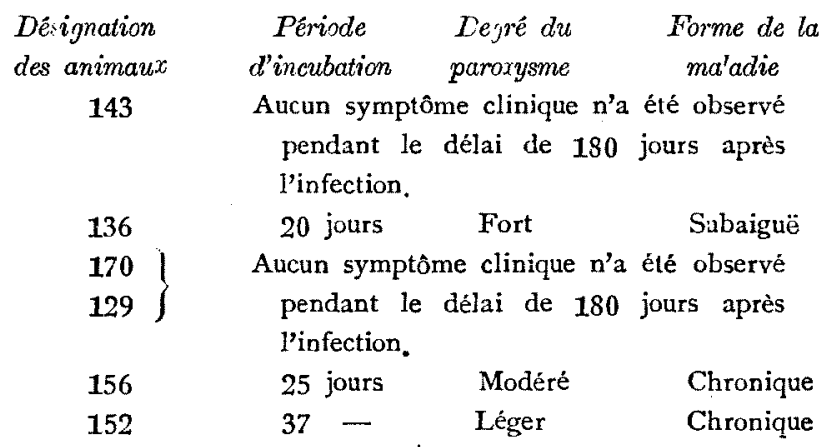

F. Cas où le virus n'a pu être demontré dans lés organe en quantité suffisante pour produire la maladie.-Le poney $\mathrm{N}^{\circ} 99$ reçut par injection sous-cutanée 0,05 centimètre cube de sang virulent. Depuis ce moment, une courbe irrégulière de température ayant été observée, on fit subir à l'animal un traitement en vue de provoquer un accès de fièvre. Par suite de ce traitement, le malade eut un accès de fièvre modéré $\left(39^{\circ} \mathrm{C}, 2\right)$ et, un mois après, un nouvel accès bénin $\left(38^{\circ} \mathrm{C}, 6\right)$ fut encore observé. Cent jours après 
le dernier accès, le malade fut abattu. Le matériel suivant a été utilisé pour le travail expérimental:

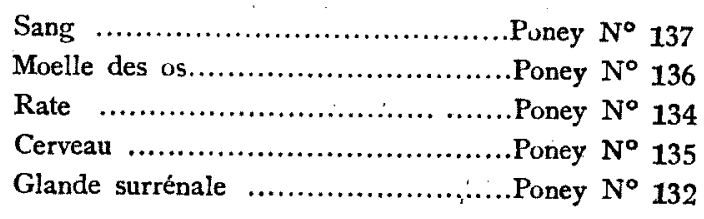

Remarques : Sang.-Erythrocytes : 7.200 .000 ; Leucocytes : 6.400 (Basophiles : 0.8 p. 100 ; Eosinophiles : 3.1 p. 100 ; Neutrophiles : 49,6 p. 100 ; Lymphocytes : 44,0 p. 100 ; Histiocytes : 2,6 p. 100); Hémoglobine : 56 p. 100.

Mcelle des os.-Légère diminution de l'érythropoièse et de la leucopoièse, beaucoup d'hémosidérine. diminution des éosinophiles et des mégacaryocytes, infiltration périvasculaire des cellules lymphoïdes.

Rate.-Infiltration marquée d'éosinophiles autour des follicules, dont le volume a augmenté. Infiltration importante de cellules lymphoïdes dans le centre germinatif et présence légère d'hémosidérine.

Cerveau.-On n'y a constaté qu'une hyperémie généralisée.

Glande surrénale.-Hyperémie marquée dans la zone réticulée et dans la partie centrale de la substance médullaire. Les cellules de la zone fasciculée présentent une importante lésion de dégénérescence avec disparition du noyau aussi bien que du protoplasma, et, dans la plupart des cellules de la zone réticulère, on observe de la pycnose et une augmentation de volume.

D'après les résultats d'une sẹrie d'expériences d'inoculation du matériel précédent, on n'a réussi, dans aucun des cas, á provoquer une infection expérimentale.

\section{Discussion}

Avant de discuter les nombreux résultats obtenus dans nos expériences, il faut avoir présent à l'esprit que le poney de Corée, utilisé danś ces essais, est extrêmement sensible á l'inoculation artificielle du virus de l'anémie contagieuse des chevaux. En 
conséquence, on peut considérer comme certains les résultats obtenus chez un tel animal d'expérience qu'on a inoculé avec du matériel varié en vue de démontrer l'existence d'un virus suffisant pour reproduire la maladie. Ainsi, l'inégalité du tableau clinique présenté par chaque animal, l'irrégularité de la période d'incubation, du degré du paroxysme et du pronostic, etc., exigent le contróle par l'action directe du virus contenu dans le matériel utilisé, bien que des différences individuelles de sensibilité soient permises. Il faut, toutefois, se rappeler que l'existence du virus dans le matériel ne peut être absolument nié lorsque l'animal ne présente aucun symptôme après l'injection, étant donné qu'il peut y avoir des cas où la teneur en virus était trop faible pour provoques l'infection.

Si l'on tient compte des considérations qui précèdent, on peut judicieusement conclure que la répartition du virus dans les divers organes n'est pas toujours la même suivant le stade évolutif de la maladie.

De plus, étant donné que, dans les divers cas de la maladie, le virus s'est trouvé en abondance dans la moelle des os, on penser que, vraisemblablement, ce virus a une affinité spécifique pour cette moelle osseuse. Si cette opinion est acceptée, on admettra aussi l'affinité spécifique du virus pour le système indifférencié "mésenchyme-réticulo-endothélial" de la moelle des os.

Il ne faut pas oublier la nature essentielle de divers virus mésodermotropes qui, dans la règle. sont habituellement décelables dans le sang pendant une certaine période de l'évolutions de la maladie, mais non à tous les moments de cette évolution. Cette notion étant admise pour l'anémie contagieuse du cheval, nous rencontrons des cas où, le virus existant dans la circulation sanguine au cours d'une période déterminée de l'évolution, est insuffisant pour reproduire la maladie. En conséquence, on ne peut conclure que le virus de l'anémie contagieuse du cheval existe toujours dans le sang de l'animal malade. Il arrivera au contraire, en pareil cas, que le virus se trouvera dans le tissu du système nerveux central de même que dans les organes endocriniens.

Mais on serait dans l'erreur si, se fondant sur ce qui précède, on considérait l'agent causal comme un virus neurotrope. Il sera- 
it plus exact, en l'état actuel de nos connaissances, de penser que le système nerveux central, comme n'importe quel organe endocrinien, est apte à la conservation du virus.

Bien que les lésions histologiques spéciales se trouvent habituellement dans la rate, dans le foie, dans les ganglions, la quantité du virus présente dans ces organes est très variable: elle est plus élevée á la première période de l'infection et pendant l'àccès fébrile qu'au cours d'une évolution prolongée. Cette variation est surtout considérable dans le foie et dans le ganglion lymphatique. En ce qui concerne le rein, et comparativement aux autres organes, l'existence du virus peut y être démontrée pendant assez longtemps, même dans le cas d'une évolution prolongée non fébrile. Ce fait est peut être imputable á ce que le virus, lors d'une évolution non fébrile, est partiellement excrété par le rein hors de l'organisme.

Il faut noter qu'en règle générale, le virus de l'anémie contagieuse des chevaux a une affinité intense pour la moelle des os et qu'il exerce ure action morbide sur le système réticuloendothélial. En même temps, cette action morbide partant de la moelle des os atteint, par la circulation du sang même, le mésenchyme de la rate, puis le mésenchyme du foie, aussi bien que celui du ganglion lymphatique, etc., et finalement le virus est décelable dans tous les tissus où pénètre le sang.

Il est, néanmoins, raisonnable de considérer que le sang ne joue dans de telles conditions que le rôle de vehicule du virus, sans qu'il y ait, dans son sein même, multiplication de ce virus. De plus, étant donné la durée prolongée d'une évolution non fébrile, la plus grande partie du virus du ganglion lymphatique, du foie et de la rate, etc., semble arriver à une extinction graduelle, sous l'influence directe des cellules des tissus telles que les cellules du système mésenchymateux. A la longue, lorsque l'existence du virus ne peut être démontrée dans la rate, sa présence dans le sang est á peine possible.

D'autre part, il faut observer que le virus peut encore être mis en évidence dans le rein, dans les mêmes conditions d'une évolution prolongée de la maladie. Il semble qu'il est très inté- 
ressant, pour l'appréciation des propriétés caractéristiques du virus. qu'il soit constaté en abondance dans la moelle osseuse, dans le cerveau et dans plusieurs organes endocriniens, même si, dans ces cas, l'existence de ce virus peut difficilement être démontrée dans les autres organes. Naturellement, il ne faut pas oublier que le virus peut être plus difficilement mis en évidence dans le cerveau et dans plusieurs autres organes endocriniens au stade de début de la maladie; qu'il y reste plus longtemps, même s'il n'existe plus dans d'autres organes, dans lesquels la circulation sanguine l'avait diffusé.

\section{Bibliographie}

(1) Mrowka: Vet. Med. Diss. Berl., 1920.

(2) Jaffe: Virch Arch., 1921, 233, 334.

(3) Ziegler: Z. f. Inf. d. Haust, 1923, 24, 242-251, 261-290. 25, 118.

(4) Eigendorf: Vet. Med, Diss, Hannover, 1923.

(5) Scott: J. of A. V. M. A., 1923, 56, 82.

(6) Schalk a. Roderik: Agri. Exp. Stat. North-Dakota Agri. Coll, 1923.

(7) Mócsy: Allatorvosi Lapok., 1924, 1-6.

(8) Zeller: Z, f. Inf. para. Kh. u. Hyg., 1924, 26, 67.

(9) Nöller u. Dobberstein: Berl. T. W., 1925, 41, 30.

(10) Ziegler: D. T. W., 1925, 33, 16.

(11) Schermer: Arch. f. wiss, u. prak. Thk., 1926, 55, 121-145.

(12) Matthiesen u. Glässer: Berl. T. W., 1926, 34, 6.

(13) Leinati: Berl. T. W., 1929, 45, 17-20.

(14) Mócsy: Arch. f. wiss. u. prak. Thk., 1932, 65, 547.

(15) Chnelewski : Vet. Med. Diss., Hannover, 1932.

(16) Janotte: Vet. Med. Diss., Hannover, 1932.

(17) Dobberstein: Berl. T. W., 1934, 50, 192-196.

(18) Mócsy: Proc, 12 th Inter. Vet. Cong., 1934, 282-292.

(19) Král :

(20) Wall : Acta, Path. et Micro. Scand., 1934, 18, 225-237.

(21) Zwick: Rap. d. l'Off. Inter. d. Epizoot., 1935.

(22) Carré e. Verge :

(23) Schmidt: Münch. T. W., 1935, 86, 33.

(24) Oellerich: Berl. T. W., 1935, 51, 23.

(25) Piening: Berl. T. W, 1935, 51, 23.

(26) Balozet: C. R. Soc. Biol., 1935, 119, 65, 160, a. 63.

(27) Ishimitsu: Jap. J. Exp. Med., 1937, 21, 9. 


\title{
馬ノ傳染性貧血病毒二關スル知見 ${ }^{*}$
}

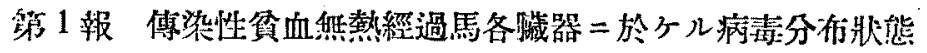

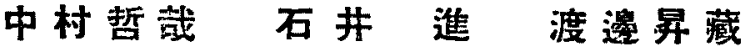

(農林省獸㾤調查所)

\author{
（炤和 13 年 9 月 1 日受附）
}

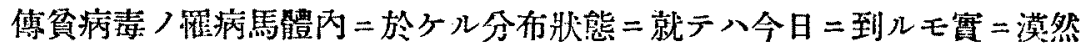

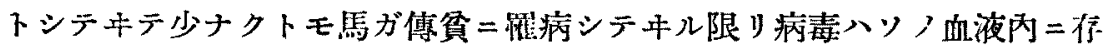
在スル（デアラウ）ト云フ極メテ概创的ナ範䁹以上ニ一步モ出テナイト云 ツテ美支ナカラウ

今, 日本馬疫調查委員會 Scott, Schalk e. Roderik等 /實駿報告 モ外敬治瘾シタト考へラレル病馬ノ血液內 =各 4 年, 12 年, 14 年ヨ經テ 化然病毒ガ存在シテキルノラ證明シタト報告シテキル此等ノ事賽入確二肯

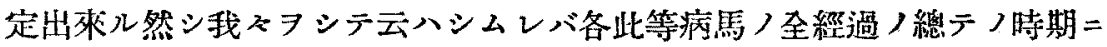
於テ常=血液內 =病素习證明シタカト云フ疑問ガアルコノ點ニ就イテハ遗

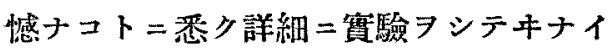

双テ我々八現在傳貧病毒＝對シテ過去ノ文缺ノ多クガ報ジテッルョウニ 血液親和性病毒トハ殆ンド考へテナナイコノ理由八他ノ報告デ述ベル管デ アル然ラバ如何ナル型ノ病毒デアルカト云フ二確答入出柬ナイガ唯分化シ タ叉末分化ノ血管壁組織二極メテ親和性ノアル事赛八確定的ノモノデアル 然モ本病毒=因ル病變八各組織站臟器ニョツテ遲速ハアルガ極メテ Pan-

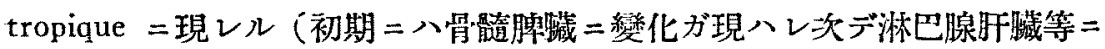

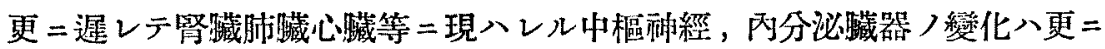

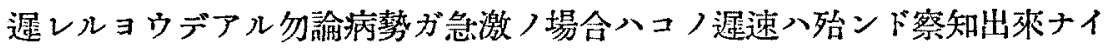
場合ガアル）以上ノョウナ點カラ考へルト傳督馬=於テ總テノ時期 $=$ 病毒 ヨ血液內二證㗅スルト云フ諭據八更二充分檢討

* 原著歐文 50-63 頁照 
唯本病毒八他種ノ病毒ノアルモノト同樣病的經過ノアル時期 $=$ 血液內 $=$ 移 行シ所謂Virémie ヨ起スモノデハナイカ然モ售貧=於デ八他ノVirusmaladie =较べテ病毒が永ク血液內二滞在シテ年ル型ノモノデハナイカ?

我くガコノ實騟

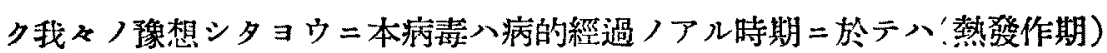

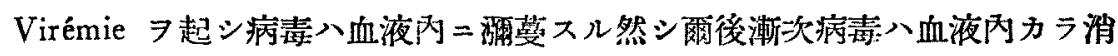
散シ經過つアル時期 =於テハ血液闪ニソノ證朋困難トナリ然モコノ時期ニ 病毒が特殊臟器= déposit métastatique スル事實マデ認メタノデアル以下 得夕成績ヨ要的シテミルト

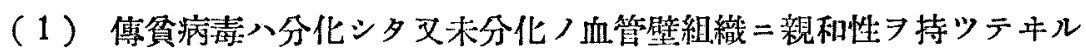
ガ就中骨髓二對スル親和性ガ最モ著朋デアルト云フノ八實驗二供シタ病馬

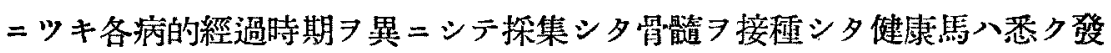
病シ然モ病勢ガ他つ践器

（2）病的經過ノアル時期二於テハ血液內二病毒ヨ殆ンド登明シナイ場

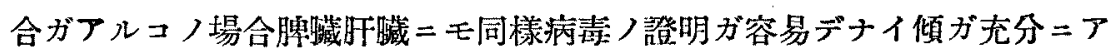
ル（朝鮮馬 176 號各臟器接種例）郎チ本痛二於テ組織學的二最モ變化ア萻

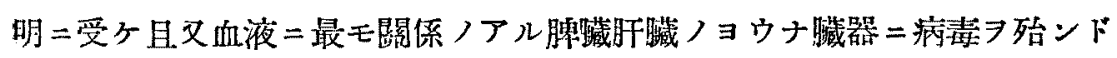
證明シ得ナカツタ（我飞ノ行ツタ實驗方法ニョツテ）事實二基ケバ本病毒 八病馬 血液內 $=$ 常 $=$ 然モ多ク證明サレルト云つ論據 $コ$ 是正シナケレバナ ラナイト同時二胳傤肝臟等二於テモ同樣ノコトガ云ハレルト思フ

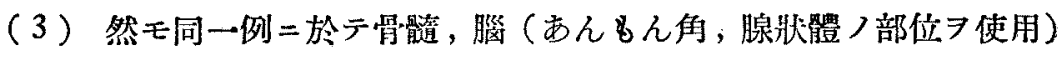

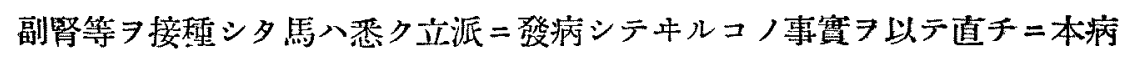

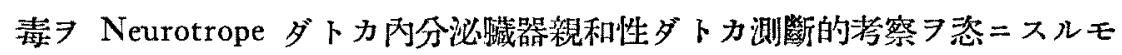
ノデヘナイ唯此等ノ間質並血管壁等二於ヶル變化ガ慢性傳貧二於テ特二著 朋デアル點（著者等つ論文, 聯並睪丸二於らル組織學的變化寥照）カラ推 シテ上述ノ事實ガ然アルベキト考へル程度デアル（传然本病八Mésenchymevirus ト若へテキル) 敦レニセヨカ、ル事實八本病毒, déposit métastatique 意味スルモノデアルト考へテ業支アルマイ 


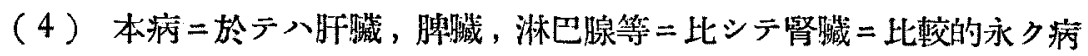

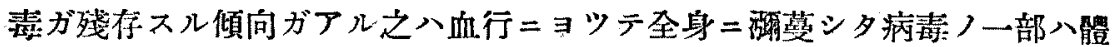

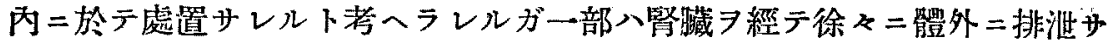
レル結果他つ臓器二較ベテ腎臟二長ク病毒ガ殘存スルモ，ト考へラレル

以上ノ記述ニョツテ明カナョウニ傳筫病毒ノ性質入今日マデ記载サレタ 各業嘖トハ相當相違ノアルコトガ知ラレル然シ遺憾ナ點八然ラバ羅病後ド ノ程度經過スルト血液內二病毒が減少シヌハ之ガ證明困難トナリ他う特殊

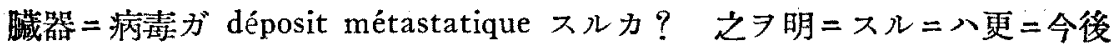
充分ナ㸴究ガ必要卜思フコノ點八病勢 =モ゙因ラウシ個體=モ關係ガアラウ 然シ我飞ノ實驗結果カラ大體次ノコトガ远ベラレルト思フ

（5） 傅貧=於テ有爇期（熱發作期）八勿諭ノコト熱分利後卜踓モ組織

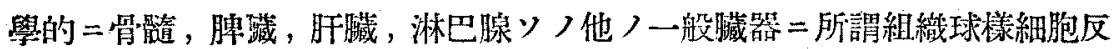
應 明シ更 $=$ 病的經過 7 經テ所謂淋巴球樣細胞反雇

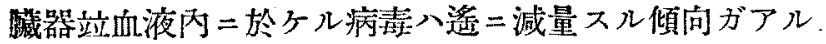

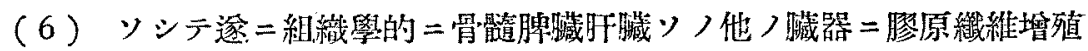

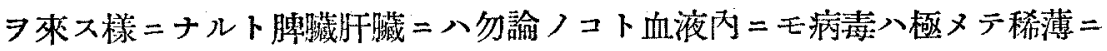
ナリ逐ニ八之ヨ證明シ得ナクナル傾问ガアルコノョウナ時期二八既逝ノョ

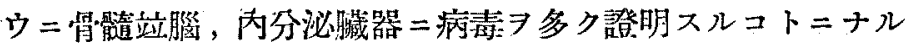

最後二我ねガ惯驗二供シタ材料ハ悉ク人工感染馬デ最後つ熱發作分利後 2 ケ月一 10 ケ月止习經過シタモノデアルコトフ附言スル 